\title{
Chlorhexidine added to different adhesive systems - Assessment of antibacterial
} activity and bond strength

\author{
Adição de clorexidlina a diferentes sistemas adesivos - Avaliação da atividade antibacteriana e \\ resistência de união \\ Adición de clorhexidina a diferentes sistemas adhesivos - Evaluación de la actividad antibacteriana \\ y fuerza de union
}

Bruna Caroline de Oliveira Lima

ORCID: https://orcid.org/0000-0002-1045-7333 Western Paraná State University, Brasil

E-mail: brcolima@hotmail.com

Thayna Carolina Zeni

ORCID: https://orcid.org/0000-0001-8917-4258 Western Paraná State University, Brasil E-mail: pelizzarithayna@live.com

Marcio José Mendonça

ORCID: https://orcid.org/0000-0002-6953-7135 Western Paraná State University, Brasil E-mail: dr.mendonca@uol.com.br

João Vitor Oribka Roque

ORCID: https://orcid.org/0000-0002-2233-7865 Western Paraná State University, Brasil E-mail: jv.oribkaroque@gmail.com Julio Katuhide Ueda

ORCID: https://orcid.org/0000-0002-8664-942X Western Paraná State University E-mail: juliouedaunioeste@gmail.com Rafael Andrade Menolli

ORCID: https://orcid.org/0000-0003-2728-8318 Western Paraná State University, Brasil E-mail: ramenolli@hotmail.com

Veridiana Camilotti

ORCID: https://orcid.org/0000-0002-3004-3939 Western Paraná State University, Brasil E-mail: vericamilotti@hotmail.com

\begin{abstract}
This study aimed to assess the effects of adding chlorhexidine (CHX) to different adhesive systems on antibacterial activity and bond strength after 24 hours and 30 days under in vitro conditions. A total of 210 bovine incisor crowns and divided into three groups, based on the adhesive system: Single Bond Plus (SB), Clearfil SE Bond (CL), and AdheSE Primer and Bond (AD). All groups were subdivided by $\mathrm{CHX}$ concentration ( $\mathrm{n}=7$ ): no $\mathrm{CHX}$, $\mathrm{CHX}$ applied before the adhesive (CPA), and the adhesive incorporated with $0.5 \% \mathrm{CHX}, 1.0 \% \mathrm{CHX}$, and $2.0 \% \mathrm{CHX}$. The micro shear test was conducted on one-half of the specimens after 24 hours, and on the other half after 30 days. Antibacterial activity was evaluated using the agar diffusion test with Streptococcus mutans. The bond strength variable was assessed using the factorial analysis of variance for repeated measurements, whereas the variable of the bacterial halo size was subjected to the Kruskal-Wallis nonparametric test. The significance level was 5\% for both tests. The qualitative variable of fracture pattern was assessed by descriptive statistical analysis. Thus, CHX concentration of $2 \%$ $(10.80 \pm 2.83)$ and CPA $(9.95 \pm 1.47)(\mathrm{p}>0.05)$ helped to increase the bond strength values for most adhesive systems, whereas CL had the highest bond strength values. The CL adhesive system also presented the best results in the antibacterial test with S.mutans.
\end{abstract}

Keywords: Chlorhexidine; Dentin-bonding agents; Anti-bacterial agents.

\section{Resumo}

Este estudo teve como objetivo avaliar os efeitos da adição de clorexidina (CHX) a diferentes sistemas adesivos sobre a atividade antibacteriana e a resistência de união após 24 horas e após 30 dias em condições in vitro. Foram selecionadas 210 coroas de incisivos bovinos e divididas em três grupos, com base no sistema adesivo: Single Bond 
Plus (SB), Clearfil SE Bond (CL) e AdheSE Primer and Bond (AD). Todos os grupos foram subdivididos pela concentração de $\mathrm{CHX}(\mathrm{n}=7)$ : sem $\mathrm{CHX}$, $\mathrm{CHX}$ aplicado antes do adesivo (CPA) e o adesivo incorporado com $0,5 \%$ de CHX, 1,0\% de CHX e 2,0\% de CHX. O teste de microcisalhamento foi realizado em metade das amostras após 24 horas e na outra metade após 30 dias. A atividade antibacteriana foi avaliada pelo teste de difusão em ágar com Streptococcus mutans. A análise da resistência de união foi feita pela análise fatorial de variância para medidas repetidas e o crescimento do halo bacteriano pelo_teste não paramétrico de Kruskal-Wallis. O nível de significância foi de 5\% para ambos os testes. A variável qualitativa do padrão de fratura foi avaliada por meio de análise estatística descritiva. Assim, a concentração de CHX de $2 \%(10,80 \pm 2,83)$ e de CPA $(9,95 \pm 1,47)(p>0,05)$ ajudaram a aumentar os valores de resistência de união para a maioria dos sistemas adesivos, onde o CL apresentou os maiores valores de resistência de união. O sistema adesivo CL também apresentou os melhores resultados no teste antibacteriano com S.mutans.

Palavras-chave: Clorexidina; Adesivos dentinários; Agente antibacteriano.

\section{Resumen}

Este estudio tuvo como objetivo evaluar los efectos de la adición de clorhexidina (CHX) a diferentes sistemas adhesivos sobre la actividad antibacteriana y la fuerza de unión después de 24 horas y después de 30 días en condiciones in vitro. Seleccionamos 210 coronas de incisivos bovinos y las dividimos en tres grupos, según el sistema adhesivo: Single Bond Plus (SB), Clearfil SE Bond (CL) y AdheSE Primer and Bond (AD). Todos los grupos se subdividieron por concentración de $\mathrm{CHX}(\mathrm{n}=7)$ : sin $\mathrm{CHX}, \mathrm{CHX}$ aplicado antes del adhesivo (CPA) y el adhesivo incorporado con $0,5 \%$ de $\mathrm{CHX}, 1,0 \%$ de $\mathrm{CHX}$ y 2,0\% de CHX. La prueba de corte transversal se realizó en la mitad de las muestras después de 24 horas y en la otra mitad después de 30 días. La actividad antibacteriana se evaluó mediante la prueba de difusión en agar con Streptococcus mutans. El análisis de la fuerza de unión se realizó mediante análisis factorial de varianza para medidas repetidas y el crecimiento del halo bacteriano mediante la prueba no paramétrica de Kruskal-Wallis. El nivel de significancia fue del 5\% para ambas pruebas. La variable cualitativa del patrón de fractura se evaluó mediante análisis estadístico descriptivo. Por lo tanto, una concentración de CHX de $2 \%$ $(10.80 \pm 2.83)$ y CPA $(9.95 \pm 1.47)$ ( p> 0.05) ayudaron a aumentar los valores de fuerza de unión para la mayoría de los sistemas adhesivos, donde CL mostró los valores de fuerza de unión más altos. El sistema adhesivo CL también mostró los mejores resultados en la prueba antibacteriana con $S$. mutans.

Palabras clave: Clorhexidina; Recubrimientos dentinarios; Antibacterianos.

\section{Introduction}

The total acid etching technique used by etch-and-rinse adhesive systems promotes micromechanical retention between dentin collagen, adhesive monomer, and composite resin. It thereby forms a hybrid layer or a dentin/resin interdiffusion zone. Despite their bonding effectiveness, these adhesives cause discrepancies between the acid demineralization depth and monomer diffusion. Dentin that is demineralized and not infiltrated by the adhesive may drive the action of matrix metalloproteinase (MMP) enzymes responsible for the long-term degradation of the hybrid layer (Breschi et al., 2010; Hajizadeh et al., 2013; Araujo et al., 2015).

The self-etching adhesives use monomers with carboxylic functional groups or phosphates. When in contact with water, these compounds are ionized, become acidic, and cross self-etching adhesives simultaneously demineralize and diffuse in the dentin, eliminating the acid-etching step. (Breschi et al., 2008). Thus, the entire extent of the demineralized dentin is infiltrated by resin monomers and decreases the action of MMPs (Strobel et al., 2015).

Different approaches have been proposed to improve the bond strength and infiltration of monomers in the demineralized dentin to reduce the rate of water absorption and the degradation of exposed collagen fibers (Breschi et al., 2008). The most frequently cited approach in the literature is to use MMP inhibitors is chlorhexidine (CHX). An amphiphilic molecule binds to various proteins by a cation-chelating mechanism. It may inhibit the catalytic activity of MMPs by binding to zinc $(\mathrm{Zn} 2+)$ or calcium $(\mathrm{Ca} 2+)$. Thus, $\mathrm{CHX}$ in the bonding protocol after phosphoric acid demineralization in dentin can stabilize the bonding interface and prevent long-term bond strength degradation. (Ricci et al., 2010).

A relationship exists between dentin collagenolytic activity and the role of MMPs in hybrid layer degradation, although the exact mechanism of how $\mathrm{CHX}$ inhibits MMPs requires further elucidation. Including $\mathrm{CHX}$ as a component of adhesive systems may aid the inhibition of MMPs and provide a practical bactericidal effect (Ou et al., 2018). This factor may 
be an alternative to suppress residual contamination after caries removal and increase the longevity of the restored tooth (Montagner et al., 2014; Ou et al., 2018). Moreover, these adhesives may prevent the colonization of bacteria in the gaps formed by the polymerization contraction of the composite resins and the degradation of the adhesive interface. However, the effects of CHX on bonding agents remain unknown (André et al., 2015).

Therefore, the aim of this in vitro study was to evaluate the effect of different concentrations of CHX incorporated into adhesives regarding micro shear tensile bond strength and antibacterial activity by adding CHX to different adhesive systems. The hypothesis of this study is to verify if the addition of CHX can inhibit the bacterial growth of $S$. Mutans without interfering in the bond strength of the selected adhesives with the dental structure.

\section{Methodology}

\section{Sample design}

The sample was calculated based on probability distributions of the F family with repeated family design and interaction within and among the factors. For bond strength analysis, the effect size was 0.15 , and type 1 error $(\alpha)$ of 0.05 and analysis power of 0.88 guaranteed a minimum of 210 sample units (i.e., specimens) with seven samples per experimental subgroup. However, for the analysis of bacterial halo formation, the minimum number of sample units was 130 specimens, with ten samples per subgroup. GPowersoftware (version 3.1.9.2; University of Düsseldorf, Düsseldorf, Germany) was used for the sample calculation. Chart 1 presents the materials used.

Chart 1 - Commercial brand names and compositions of the materials used in the study.

\begin{tabular}{|c|c|c|}
\hline Trademark, Acronym & Manufacturer & Composition \\
\hline $\begin{array}{l}\text { Phosphoric Acid- } \\
\text { Condac } 37 \% \text {, AF }\end{array}$ & $\begin{array}{lll}\text { FGM } & \text { (Joinville, } & \text { SC, } \\
\text { Brazil }) & \end{array}$ & $\begin{array}{l}37 \% \text { Phosphoric acid, thickener, dye and deionized } \\
\text { water }\end{array}$ \\
\hline Single Bond Plus, SB & $\begin{array}{l}\text { 3M ESPE (Sumaré SP, } \\
\text { Brazil) }\end{array}$ & $\begin{array}{l}\text { Alcohol, water, silica treated silica, bis-GMA, HEMA, dimethacrylates, } \\
\text { ethanol, water, polyacrylic and polyalkanoic acid methacrylate functional } \\
\text { copolymer camphorquinone, dimethacrylate, } 10 \% \text { by weight of } \\
\text { silica nanoparticles ( } 5 \text { nanometers). }\end{array}$ \\
\hline Clearfil SE, CL & Kuraray (Osaka, Japan) & $\begin{array}{l}\text { Primer: 10-MDP, HEMA, } \\
\text { dimethacrylate, water. } \\
\begin{array}{l}\text { Adhesive: } \quad \text { 10-MDP, } \\
\text { camphorquinone, hydrophobic methacrylate. }\end{array}\end{array}$ \\
\hline AdheSE, AD & $\begin{array}{l}\text { IvoclarVivadent (Barueri, } \\
\text { SP, Brazil) }\end{array}$ & $\begin{array}{l}\text { AdheSE Primer:dimethacrylate, phosphonic } \text { acid acrylate, } \\
\text { initiators and stabilizers in aqueous solution. } \\
\text { AdheSE Bond: HEMA, dimethacrylate, silicon dioxide, } \\
\text { initiators and stabilizers. }\end{array}$ \\
\hline $\begin{array}{l}\text { Composite Resin Opus } \\
\text { Bulk FillFlow, RC }\end{array}$ & $\begin{array}{l}\text { FGM (Joinville, SC, } \\
\text { Brazil) }\end{array}$ & $\begin{array}{l}\text { Uretanadimetacrylic monomers, } \\
\text { camphorquinone and coinhibitor. Inorganic loads of silicon dioxide, silanized, } \\
\text { stabilizers and pigments. }\end{array}$ \\
\hline $\begin{array}{l}20 \% \quad \text { Chlorhexidine } \\
\text { digluconate, } \mathrm{CHX}\end{array}$ & $\begin{array}{l}\text { Manipulated Pharmacy- } \\
\text { Santa Terezinha (Paraná, } \\
\text { Brazil) }\end{array}$ & $20 \% \mathrm{CHX}$ \\
\hline
\end{tabular}




\section{Preparation of materials}

Different amounts of 20\% chlorhexidine digluconate (Manipulated-Farmácia, Santa Terezinha-Laranjeiras do Sul, Paraná, Brazil) were added directly to the adhesives for the preparation of mixtures at CHX concentrations of $0.5 \%, 1 \%$, and 2\%. These concentrations were obtained using high-precision pipettes (Micropipette Monocanal Variable Volume-Ecopipette; Capp, Odense, South Denmark) in a controlled environment (Laboratory of Immunology and Virology at Western Paraná State University, Cascavel, PR, Brazil).

The $0.5 \%$ concentration was achieved by combining $25 \mu \mathrm{L}$ of $\mathrm{CHX}$ in $975 \mu \mathrm{L}$ of primer or adhesive, depending on the group (Figure 1); the $1 \%$ concentration, by combining $50 \mu \mathrm{L}$ of $\mathrm{CHX}$ in $950 \mu \mathrm{L}$ of primer or adhesive; and the $2 \%$ concentration, by combining $100 \mu \mathrm{L}$ of $\mathrm{CHX}$ in $900 \mu \mathrm{L}$ of primer or adhesive. The solutions were stored in Eppendorf tubes (3810X; Eppendorf do Brasil, São Paulo, SP, Brazil), which were properly sealed, protected from light, and refrigerated in a conventional refrigerator at $7^{\circ} \mathrm{C}$ until use (Carrilho et al., 2007).

Figure 1 - Distribution of the experimental groups $(n=7)$.

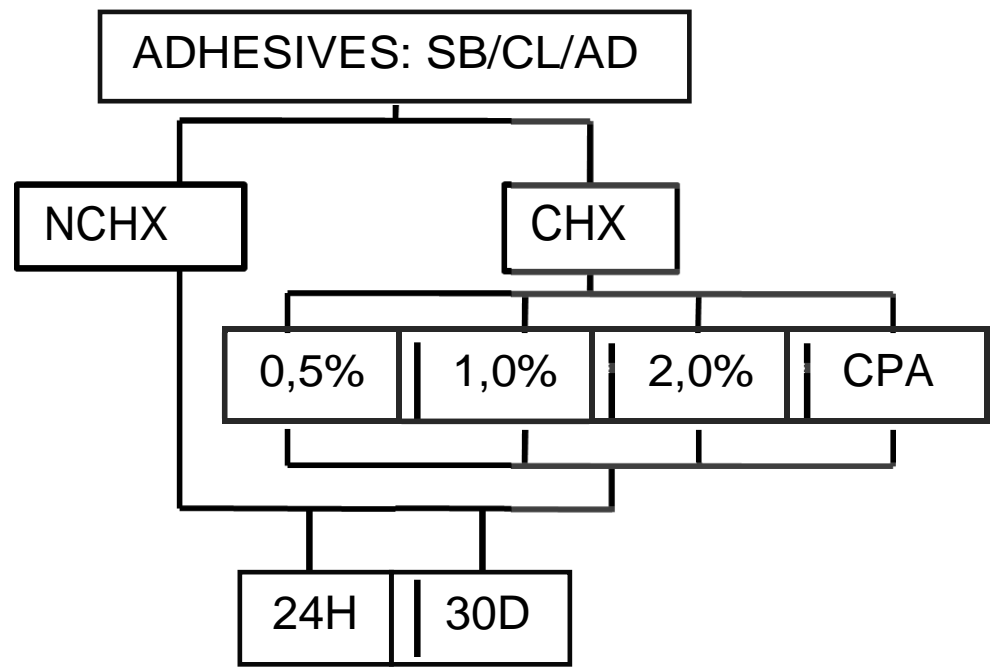

There are 35 samples in total with $\mathrm{n}=7$ per subgroup according to the concentration or not of chlorhexidine. Legends - 105 specimens were made for 24 hours and another 105 for 30 days. Source: Authors (2022).

\section{Preparation of the specimens}

Two hundred ten bovine incisors were selected, based on the sample calculation. They were freshly extracted, free of periodontal tissue, and stored in $1 \%$ thymol solution under refrigeration for thirty days. The teeth were sectioned with high rotation under abundant cooling by using a diamond bur \#4138 (KG Sorensen,Cotia, SP, Brazil) to separate the crown from the root. The crowns were then inserted in polyvinyl chloride tubes with acrylic resin. The buccal surface remained free. A polisher (Aropol 2V200; Arotec S.A. Industry and Business, Cotia, SP, Brazil) with sandpaper discs from the highest to the lowest granulation of \#600 was used to grind down the tooth enamel on the buccal face until the enamel was completely removed and the dentin was exposed (Suma et al., 2017). The elements were then stored in distilled water at $37^{\circ} \mathrm{C}$ until the time of use.

The composite resin cylinders were produced using Tygon tubing (TYG-030; Saint-Gobain Performance Plastic, Maimi Lakes, FL, USA) with an internal diameter of $1 \mathrm{~mm}$ and height of $2 \mathrm{~mm}$. By using clinical tweezers, the tubing was placed on the tooth surface. The specimens were produced with Bulk Fill Flow composite resin (Opus Bulk Fill Flow; FGM, Joinville, SC, Brazil) in a single photo activated increment for 20 seconds with a light-emitting diode (LED) light device with 
an irradiance of $1200 \mathrm{~mW} / \mathrm{cm}^{2}$ (Bluephase G2; Ivoclar_Vivadent, Barueri, SP, Brazil). Three composite resin cylinders were created for each bovine crown to perform a triplicate test, thereby eliminating any bias. The average was calculated for each tooth. One-half of the specimen was stored for 24 hours in relative humidity at $37^{\circ} \mathrm{C}$. It there after underwent the microshear test. The other half of the specimen was stored for 30 days in distilled water at $37^{\circ} \mathrm{C}$, which was changed every 15 days. Finally, the specimens underwent the microshear test.

\section{Microshear bond strength test and fracture analysis}

The composite resin cylinders were tested in a universal testing machine (DL 200-MF; EMIC, São José dos Pinhais, PR, Brazil) with a load cell of $20 \mathrm{~kg}$. The shear load with $0.2-\mathrm{mm}$ orthodontic wire was applied to the base of the cylinders at a speed of $0.5 \mathrm{~mm} / \mathrm{min}$ until rupture. The microshear bond strength was calculated and expressed in mega-Pascals (MPa). The failure modes were assessed using a stereoscopic magnifying glass with $40 \times$ magnification $_{2}$ and the classification followed the criteria recommended in International Organization for Standardization TR 11405. An adhesive fracture was a failure at the adhesive/dentin interface; an adhesive-cohesive fracture was failure exclusively within the adhesive; and a mixed fracture was adhesive/dentin/resin interface failures, which included cohesive failures in neighboring substrates.

\section{Antibacterial activity test}

The agar diffusion test (ADT) was conducted on blood agar plates in which $200 \mu \mathrm{L}$ of freshly grown Streptococcus mutans were evenly distributed on plates with a sterile swab. In each of nine plates, ten 4-mm diameter circular holes were drilled, one hole for each solution, up to the end of a sterile 4-mm diameter Pasteur pipette. The 10 holes of each plate were immediately filled with $50 \mu \mathrm{L}$ of the nine adhesive testing solutions and then polymerized using an LED light device with an irradiance of $1200 \mathrm{~mW} / \mathrm{cm}^{2}$ (Bluephase G2, Ivoclar_Vivadent), based on the manufacturer's instructions.

The 10 perforations (4-mm diameter) were filled with solutions containing CHX at concentrations of $0.5 \%$, $1 \%$, and $2 \%$ in the primer (Clearfil SE Bond [CL; Kuraray, Osaka, Japan] and AdheSE Primer and Bond [AD; Ivoclar_Vivadent, Barueri, São Paolo, SP, Brazil]) or in the adhesive (Single Bond Plus [SB; 3M-ESPE, Sumaré, SP, Brazil])._The agar plates were incubated for 48 hours at $37^{\circ} \mathrm{C}$, and then inspected for an inhibition halo. The inhibition halo diameter was measured twice perpendicularly by using a digital caliper (Starret727; Starret, Itu, SP, Brazil) with an accuracy of $0.0001 \mathrm{~mm}$ (Penmetsa et al., 2014).

\section{Statistical analysis}

The statistical analyses were conducted with Bioestat 5.3 software (Instituto Mamirauá, 2007). The data for quantitative variables (i.e., bond strength and bacterial halo size) were initially assessed by distribution type using the ShapiroWilk test. The data did not adhere to the normality curve. Therefore, the Mann-Whitney test $(\mathrm{p}<0.05)$ was used to compare the two groups. For other comparisons, the Kruskal-Wallis analysis of variance was used, followed by the Dunn test to analyze the interaction between the groups $(\mathrm{p}<0.05)$. The qualitative variable (i.e., fracture pattern) was assessed by descriptive statistical analysis.

\section{Results}

The CHX concentration used in this experiment after 24 hours produced the lowest statistically significant values at $1 \%$ for the SB adhesive. At the concentration of $0.50 \%$, all adhesive systems were statistically similar. At the $2 \%$ concentration, the CL adhesive system showed significantly higher values than the other systems. 
For CL, applying CHX before the adhesive (i.e., CPA) produced values similar to those of the $2 \%$ concentration. Changing the CHX concentration or using CPA after 24 hours did not change the values obtained for the AD adhesive.

The SB adhesive systemfor CHX concentration of $2 \%$ had significantly lower results than those of the other adhesive systems. Applying CPA showed the best values for CL and the lowest values for SB and AD (Table 1).

Table 1 - The mean values and standard deviations of the bond strength variable (in MPa), based on adhesive type and CHX concentration, at 24 hours.

\begin{tabular}{|c|c|c|c|c|c|c|c|}
\hline \multicolumn{2}{|c|}{ Solutions / Adhesives } & \multicolumn{2}{|r|}{ SB } & \multicolumn{2}{|r|}{$\mathbf{C L}$} & \multicolumn{2}{|r|}{ AD } \\
\hline \multirow{5}{*}{$\begin{array}{c}24 \\
\text { hours }\end{array}$} & $0 \%$ & 6,99 & $( \pm 1,95) \mathrm{ABa}$ & 8,24 & $(+2,73) \mathrm{ABa}$ & 9,66 & $(+3,30) \mathrm{Aa}$ \\
\hline & $\mathbf{0 , 5 0 \%}$ & 8,72 & $(+2,10) \mathrm{Aa}$ & 7,99 & $(+2,26) \mathrm{ABa}$ & 7,23 & $(+2,16) \mathrm{Aa}$ \\
\hline & $1,00 \%$ & 3,64 & $(+1,56) \mathrm{Ba}$ & 6,01 & $(+0,90) \mathrm{Aab}$ & 7,06 & $(+1,99) \mathrm{Ab}$ \\
\hline & $2,00 \%$ & 7,17 & $(+1,72) \mathrm{ABa}$ & 10,80 & $(+2,83) \mathrm{Bb}$ & 7,49 & $(+0,77) \mathrm{Aab}$ \\
\hline & CPA & 6,07 & $(+1,41) \mathrm{ABa}$ & 9,95 & $(+1,47) \mathrm{Bb}$ & 6,64 & $(+2,49) \mathrm{Aa}$ \\
\hline
\end{tabular}

Different letters indicate statistically significant differences, lowercase letters for row and upper-case for the column, $\mathrm{p}<0.05$. Legends: CHX: chlorhexidine; - SB $=$ Single Bond Plus; $\mathrm{CL}=$ Clearfil SE; AD = AdheSE; CPA = applying CHX before the adhesive. Source: Authors (2022).

SB had the highest frequency of reduced bond strength values (Table 2). The best values for the CHX factor occurred with the CL adhesive at 0,5 and $1 \%$, while the lowest values occurred with the AD and SB adhesives at $1 \%$ concentration. The SB adhesive had the lowest bond strength values for CPA, and the CL and AD adhesives had the highest values.

Table 2 - The mean values and standard deviations of the bond strength variable (in MPa), based on the_adhesive type and CHX concentration, at 30 days.

\begin{tabular}{|c|c|c|c|c|c|c|c|}
\hline \multicolumn{2}{|c|}{ Solutions / Adhesives } & \multicolumn{2}{|r|}{ SB } & \multicolumn{2}{|r|}{ CL } & \multicolumn{2}{|r|}{ AD } \\
\hline \multirow{5}{*}{30 days $[\mathrm{CHX}]$} & $0 \%$ & 7,48 & $(+4,17) \mathrm{Aa}$ & 11,23 & $(+2,25) \mathrm{ABa}$ & 10,28 & $(+1,54) \mathrm{Aa}$ \\
\hline & $0,50 \%$ & 5,73 & $(+0,95) \mathrm{Aa}$ & 10,00 & $(+1,98) \mathrm{ABb}$ & 9,94 & $(+5,87) \mathrm{ABab}$ \\
\hline & $1,00 \%$ & 5,64 & $(+2,40) \mathrm{Aa}$ & 12,47 & $(+3,00) \mathrm{Ab}$ & 6,13 & $(+1,55) \mathrm{Ba}$ \\
\hline & $2,00 \%$ & 6,84 & $(+1,94) \mathrm{Aa}$ & 9,45 & $(+1,81) \mathrm{ABa}$ & 8,33 & $(+2,65) \mathrm{ABa}$ \\
\hline & CPA & 4,23 & $(+0,96) \mathrm{Aa}$ & 7,93 & $(+2,89) \mathrm{Bb}$ & 6,95 & $(+1,11) \mathrm{ABb}$ \\
\hline
\end{tabular}

Different letters indicate statistically significant differences, lowercase letters for row and upper case for column, $\mathrm{p}<0.05$. Legends: CHX: chlorhexidine; SB = Single Bond Plus; CL = Clearfil SE; AD = AdheSE; CPA: applying CHX before the adhesive. Source: Authors (2022).

On analyzing the influence of storage time (i.e., 24 hours and 30 days) on the experimental groups, the results indicated that time did not affect the bond strength of samples for most combinations. This finding occurred in all groups with the AD adhesive. The bond strength values decreased with the SB adhesive at the concentration of $0.5 \%$ and with CPA after the storage period, the concentrations of $0 \%, 1 \%$ and $\%$ did not present significant differences. By contrast, the CL adhesive values at the $0 \%$ and $1 \%$ concentrations increased after 30 days (Table 3). 
Table 3 - The mean values and standard deviations of the bond strength variable (in MPa), based on adhesive type and CHX concentration, at 24 hours and at 30 days.

\begin{tabular}{|c|c|c|c|c|}
\hline Adhesives & $\begin{array}{c}\text { Concentration of } \\
\text { CHX }\end{array}$ & 24 hours & 30 days & p-value \\
\hline \multirow{5}{*}{ SB } & $0 \%$ & $6,99( \pm 1,95)$ & $7,48( \pm 4,17)$ & 0,9491 \\
\hline & $0,50 \%$ & $8,72( \pm 2,10)$ & $5,73( \pm 0,95)$ & $0,0088 *$ \\
\hline & $1,00 \%$ & $3,64( \pm 1,56)$ & $5,64( \pm 2,40)$ & 0,1417 \\
\hline & $2,00 \%$ & $7,17( \pm 1,72)$ & $6,84( \pm 1,94)$ & 0,5653 \\
\hline & CPA & $6,07( \pm 1,41)$ & $4,23( \pm 0,96)$ & $0,0253 *$ \\
\hline \multirow{5}{*}{ CL } & $0 \%$ & $8,24( \pm 2,73)$ & $11,23( \pm 2,25)$ & $0,0253 *$ \\
\hline & $\mathbf{0 , 5 0 \%}$ & $7,99( \pm 2,26)$ & $10,00( \pm 1,98)$ & 0,1417 \\
\hline & $1,00 \%$ & $6,01( \pm 0,90)$ & $12,47( \pm 3,00)$ & $0,0017 *$ \\
\hline & $2,00 \%$ & $10,80( \pm 2,83)$ & $9,45( \pm 1,81)$ & 0,2774 \\
\hline & CPA & $9,95( \pm 1,47)$ & $7,93( \pm 2,89)$ & 0,1417 \\
\hline \multirow{5}{*}{ AD } & $0 \%$ & $9,66( \pm 3,30)$ & $10,28( \pm 1,54)$ & 0,9491 \\
\hline & $\mathbf{0 , 5 0 \%}$ & $7,23( \pm 2,16)$ & $9,94( \pm 5,87)$ & 0,3379 \\
\hline & $1,00 \%$ & $7,06( \pm 1,99)$ & $6,13( \pm 1,55)$ & 0,4062 \\
\hline & $2,00 \%$ & $7,49( \pm 0,77)$ & $8,33( \pm 2,65)$ & 0,7494 \\
\hline & CPA & $6,64( \pm 2,49)$ & $6,95( \pm 1,11)$ & 0,9490 \\
\hline
\end{tabular}

*: Statistically significant differences, $\mathrm{p}<0.05$. Legends: CHX: chlorhexidine; SB = Single Bond Plus; CL = Clearfil SE; AD = AdheSE; $\mathrm{CPA}=$ applying CHX before the adhesive; MPa: mega-Pascal. Source: Authors (2022).

The statistical comparison between the same adhesive with different CHX concentrations revealed higher values for bacterial halo formation, most often at $2 \% \mathrm{CHX}$, and the lowest values at $0 \% \mathrm{CHX}$. However, the same $\mathrm{CHX}$ concentration analysis between different adhesives showed that CL presented the best statistically significant results in most comparisons. In contrast, in most comparisons, SB presented the worst growth values of the bacterial inhibition halo (Table 4).

Table 4 - The mean values and standard deviations (in millimeters) of the bacterial inhibition halo reading in the experimental groups.

\begin{tabular}{|c|c|c|c|c|c|c|c|c|}
\hline [CHX]/Adhesives & & SBL & & $\mathbf{C L}$ & & AD & & CHX \\
\hline $0 \%$ & 0,00 & $(+0,00) \mathrm{Aa}$ & 1,13 & $(+0,09) \mathrm{Ab}$ & 1,85 & $(+0,21) \mathrm{ABc}$ & & - \\
\hline $\mathbf{0 , 5 0 \%}$ & 0,76 & $(+0,19) \mathrm{Aa}$ & 2,43 & $(+0,16) \mathrm{Bb}$ & 1,96 & $(+0,14) \mathrm{Ac}$ & & - \\
\hline $1,00 \%$ & 1,57 & $(+0,57) \mathrm{Ba}$ & 2,71 & $(+0,18) \mathrm{Bb}$ & 1,76 & $(+0,21) \mathrm{ABa}$ & & - \\
\hline $2,00 \%$ & 2,38 & $(+0,16) \mathrm{Ba}$ & 2,55 & $(+0,13) \mathrm{Ba}$ & 1,64 & $(+0,26) \mathrm{Bb}$ & 2,45 & $(+0,21) \mathrm{a}$ \\
\hline
\end{tabular}

Different letters indicate statistically significant differences, lowercase letters for row and upper case for the column, $\mathrm{p}<0.05$. Legends: CHX: chlorhexidine; $\mathrm{SB}=$ Single Bond Plus; $\mathrm{CL}=$ Clearfil SE; $\mathrm{AD}=$ AdheSE; $\mathrm{CPA}=$ applying CHX before the adhesive. Source: authors (2022).

Figure 2 presents the absolute frequency of adhesive, mixed, and adhesive-cohesive fractures in SB, CL, and AD at 24 hours and at 30 days. After 30 days of experimentation, the occurrence of adhesive fractures was highest for AD (63\%); at 24 
hours, it was highest for SB (51\%). At 30 days, cohesive fractures were highest for SB (55\%), followed by CL (52\%). At 24 hours, mixed fractures were lowest (4\%) for SB and highest (29\%) for CL.

Figure 2 - Frequency distributions of the failure types among the experimental groups at 24 hours (24H) and 30 days (30D).

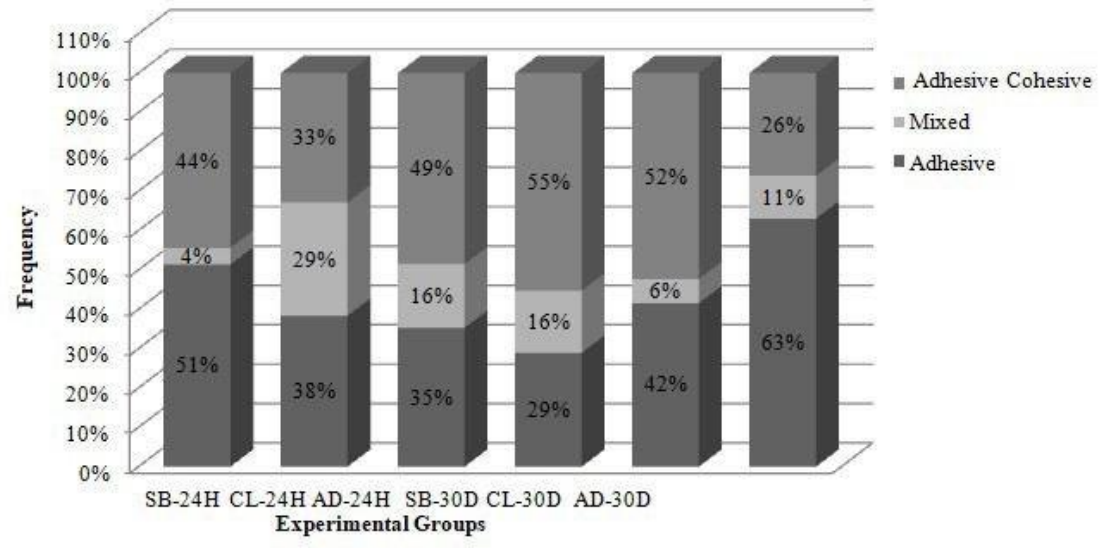

Legends: CHX: chlorhexidine; $\mathrm{SB}=$ Single Bond Plus; $\mathrm{CL}=$ Clearfil SE; AD = AdheSE; CPA = applying CHX before the adhesive. Source: Authors (2022).

\section{Discussion}

The present study aimed to contribute to clarifying the role of CHX concentration in inhibiting MMPs because the literature remains controversial (Breschi et al., 2010; Perote et al., 2015; Ou et al., 2018). The findings of this study indicated better bond strength for CL when adding 2\% CHX and using CPA within 24 hours, and with $0 \%$ and $0.5 \%$, there was no statistical difference between them. These findings agree with literature reports demonstrating significant improvement in bond strength when using 2\% CHX; this concentration may be effective in inhibiting MMPs (Carrilho et al., 2007; Breschi et al., 2010; Stanislawczuk et al., 2014).

A 2-year clinical study in which CHX was added to the primer of two adhesives (i.e., AD and CL) did not show clinical benefits at the assessed periods. However, in one study (Araujo et al., 2015), CL presented a better retention rate for restorations, compared with AD. At 24 hours, CL was superior to SB, not different from AD with $2 \%$ CHX. However, at 30 days, there was no difference between groups for the same concentration.

The comparative analysis between the experimental groups showed that SB more often had lower bond strength values. This finding may be related to the fact that SB, a conventional adhesive, requires $37 \%$ phosphoric acid etching, which removes the smear layer and leaves the collagen fibrils exposed because of incomplete infiltration of the resin monomers. This process then activates MMPs (Hashimoto et al., 2018). By contrast, the CL and AD adhesives are self-etching, the difference between these two self-etching adhesives is in the composition: AD contains the 2-hydroxyethylmethacrylate monomer and CL contains the 10-methacryloyloxydecyl dihydrogen phosphate monomer. The chemical binding promoted by 10methacryloyloxydecyl dihydrogen phosphate is more effective and more stable in an aqueous environment, compared with that achieved by hydroxyethylmethacrylate, 4-(2-methacryloxyethoxycarbonyl) phthalic anhydride, and phenyl-P monomers (Van Landuty et al., 2006). This factor may have contributed to increased bond strength after the 30-day period without the addition of CHX and the addition of 1\% (Hashimoto et al., 2018), Osorio and collaborators (2008) had similar results. 
The use of an MMP inhibitor on the dentin surface before applying the adhesive or incorporating it into the adhesive system may improve the stability and integrity of the adhesive interface over time (De Munck et al., 2010; Li et al., 2015; Tekce et al., 2016). Thus, when comparing the bond strength values relative to the CHX concentration versus time, CL showed a significant improvement after 30 days with 1\%; however, SB showed a decrease after 30 days with $0,5 \%$.

For AD, there were no statistically significant differences at 24 hours and at 30 days. Similar results were observed by Gunaydin and collaborators (2016). In their study, pretreatment with $2 \%$ CHX produced higher bond strength values than those of samples without pretreatment, which indicated that using CHX produced better adhesive interface stability.

A difference between fracture types is expected when using different adhesive strategies and when using different mechanical tests. In this study, AD showed the highest occurrence of adhesive fractures after 30 days of storage (63\%) but showed the highest occurrence of cohesive fractures at 24 hours. This finding suggested satisfactory bond strength after the aging period because adhesive fractures indicate a better force distribution (Rocha et al., 2007).

It has long been believed that cohesive fractures in dentin result from high bond strength because the higher bond strength achieved with adhesive systems tested in large areas by tensile tests promoted an irregular force distribution, and thus led to fractures in the dentin but not at the adhesive interface. Thus, a cohesive fracture occurs. As the dentin fractured, the bond strength in the dentin/resin interface was higher than the cohesive strength of dentin. Therefore, an adhesive fracture would correspond to a low bond strength.

After the introduction of the microshear and microtensile tests (Sano et al., 1994), the current study verified that the lower the adhesive area, the lower was the possibility of defects in the tooth surface that negatively interfere with bond strength. Thus, regardless of the test used - microshear or microtensile - the uniform distribution of forces indicate that fracture patterns should be mixed and adhesive (Rocha et al., 2007).

The ADT also showed significantly superior behavior with the CL adhesive, compared with the other adhesive systems or the control at 2\% CHX. This finding showed that, among the CHX adhesive systems, CL had higher antibacterial properties than the other tested adhesives at 72 hours after polymerization. Similar results were achieved in 2014 by Kim \& Shin (2014) who tested the CL adhesive and other adhesive system by using $0.12 \%$ CHX and $37 \%$ phosphoric acid as the positive controls. They found that the antibacterial activity of $0.12 \% \mathrm{CHX}$ and $37 \% \mathrm{PA}$ gel was stronger than that of the other groups, except for CL, which had the highest inhibition halo.

The antibacterial activity of adhesive systems depends on several factors such as $\mathrm{pH}$, which for the CL adhesive is approximately 2.0; the presence of antibacterial components in the chemical composition; and the viscosity of the material inhibition (Gondim et al., 2008). Thus, the acidic nature of the primer of self-etching adhesive systems may be a main factor associated with bacterial inhibition (Gondim et al., 2008). Adding CHX or using it before applying an adhesive system at a certain concentration (in this instance, 2\%) may improve bond strength and aid inactivating MMPs. However, further clinical studies are required to define the concentration and time for optimum application. However, because efficient in vitro performance may improve clinical performance, it needs to be determined whether the growth-inhibiting effects of the dentin adhesives observed in this study would be similar in vivo.

\section{Conclusion}

The findings of this in vitro study suggest (1) the concentration of $2 \% \mathrm{CHX}$, whether incorporated into the primer or applied separately before the adhesive, aided the increase in the bond strength values and (2) the CL adhesive system showed the best results in the antibacterial test with Streptococcus mutans. To complement the findings of this study, future research such as laboratory test of nanoleakage and randomized clinical trials would be of great value. 


\section{References}

André, C. B., Gomes, B. P., Duque, T. M., Stipp, R. N., Chan, D. C. \& Ambrosano, G. M. (2015). Dentine bond strength and antimicrobial activity evaluation of adhesive systems. Journal of Dentistry, 43(4), 466-75.

Araújo, M. S., Souza, L. C., Apolonio, F. M., Barros, L. O., Reis, A. \& Loguercio, A. D. (2015) Two-year clinical evaluation of chlorhexidine incorporation in two-step self-etch adhesive. Journal of Dentistry, 43(1),140-8.

Breschi, L., Mazzoni, A., Nato, F., Carrilho, M., Visintini, E. \& Tjäderhane, L. (2010). Chlorhexidine stabilizes the adhesive interface: a 2-year in vitro study. Dental Materials, 26(4), 320-5.

Breschi, L., Mazzoni, A., Ruggeri, A., Cadenaro, M., Di Lenarda, R. \& De Stefano, E. (2008). Dental adhesion review: aging and stability of the bonded interface. Dental Materials, 24(1), 90-101.

Carrilho, M. R., Carvalho, R. M., de Goes, M. F., di Hipólito, V., Geraldeli, S., \& Tay, F. R. (2007). Chlorhexidine preserves dentin bond in vitro. Journal of Dental Research, 86(1), 90-4.

Munck, J., Mine, A., Van den Steen, P. E., Van Landuyt, K. L., Poitevin, A. \& Opdenakker, G. (2010). Enzymatic degradation of adhesive-dentin interfaces produced by mild self-etch adhesives. European Journal of Oral Science, 118(5), 494-501.

Gondim, J.O., Duque, C., Hebling, J. \& Giro, E.M. (2008). Influence of human dentine on the antibacterial activity of self-etching adhesive systems against cariogenic bacteria. Journal of Dentistry, 36(4), 241-8.

Gunaydin, Z., Yazici, A.R., Cehreli, Z.C. (2016). In vivo and in vitro effects of chlorhexidine pretreatment on immediate and aged dentin bond strengths. Operative Dentistry, 41(3), 258-67.

Hajizadeh, H., Ghavamnasiri, M. \& Majidinia, S. (2013). Randomized clinical evaluation of the effect of chlorhexidine on postoperative sensitivity of posterior composite resin restorations. Quintessence International, 44(10), 793-8.

Hashimoto, M., Hirose, N., Kitagawa, H., Yamaguchi, S., Imazato, S. (2018). Improving the durability of resin-dentin bonds with an antibacterial monomer MDPB. Dental Materials Journal, 37(4),620-7.

Kim, S.R. \& Shin, D.H. (2014) Antibacterial effect of self-etching adhesive systems on Streptococcus mutans. Restorative Dentistry \& Endodontics, 39(1), 32-

Li, H., Li, T., Li, X., Zhang, Z., Li, P. \& Li, Z. (2015). Morphological effects of MMPs inhibitors on the dentin bonding. International Journal of Clinical and Experimental Medicine, 8(7),10793-803.

Montagner, A.F., Sarkis-Onofre, R., Pereira-Cenci, T. \& Cenci, M.S. (2014). MMP inhibitors on dentin stability: a systematic review and meta-analysis. Journal of Dental Research, 93(8), 733-43.

Osorio, R., Pisani-Proenca, J., Erhardt, M.C., Osorio, E., Aguilera, F.S. \& Tay, F.R. (2008). Resistance of ten contemporary adhesives to resin-dentine bond degradation. Journal of Dentistry, 36(2), 163-9.

Ou, Q., Hu, Y., Yao, S., Wang, Y. \& Lin, X. (2018). Effect of matrix metalloproteinase 8 inhibitor on resin-dentin bonds. Dental Materials, $34(5), 756-63$.

Penmetsa, R.K., Rekha, A.S., Poppuri, K.C., Prashanth, P.S. \& Garapati S. (2014). An in vitro evaluation of antibacterial properties of self-etching dental adhesive systems. Journal of Clinical and Diagnostic Research, 8(7), 1-5.

Perote, L.C., Kamozaki, M.B., Gutierrez, N.C., Tay, F.R. \& Pucci, C.R. Effect of matrix metalloproteinase-inhibiting solutions and aging methods on dentin bond strength. Journal of Adhesive Dentistry, 17(4), 347-52.

Ricci, H.A., Sanabe, M.E., Costa, C.A. \& Hebling, J (2010). Effect of chlorhexidine on bond strength of two-step etch-and-rinse adhesive systems to dentin of primary and permanent teeth. American Journal of Dentisty, 23(3), 128-32.

Rocha, R., Soares, F.Z., Rodrigues, C.R. \& Rodrigues Filho, L.E. (2007). Influence of aging treatments on microtensile bond strength of adhesive systems to primary dentin. Journal of Dentistry for Children, 74(2), 109-12.

Sano, H., Shono, T., Sonoda, H., Takatsu, T., Ciucchi, B. \& Carvalho, R.M. (1994). Relation between surface area for adhesion and tensile bond strength evaluation of a micro-tensile bond test. Dental Materials, 10(4), 236-40.

Stanislawczuk, R., Pereira, F., Muñoz, M.A., Luque, I., Farago, P.V. \& Reis, A. (2014). Effects of chlorhexidine-containing adhesives on the durability of resin-dentine interfaces. Journal of Dentistry, 42(1), 39-47.

Strobel, S. \& Hellwig, E. (2015). The effects of matrix-metallo-proteinases and chlorhexidine on the adhesive bond. Swiss Dental Journal, 125(2),134-45.

Suma, N.K., Shashibhushan, K.K. \& Reddy, V.V.S. (2017). Effect of dentin disinfection with $2 \%$ chlorhexidine gluconate and $0.3 \%$ iodine on dentin bond strength: an in vitro study. International Journal of Clinical Pediatric Dentistry, 10(3), 223-8.

Tekçe, N., Tuncer, S., Demirci, M. \& Balci S. (2016). Do matrix metalloproteinase inhibitors improve the bond durability of universal dental adhesives? Scanning, 238(6), 535-44.

Van Landuyt, K.L., Kanumilli, P., De Munick, J., Peumans, M., Lambrechts, P. \& Van Meerbeek, B. (2006). Bond strength of a mild self-etch adhesive with and without prior acid-etching. Journal of Dentistry, 34(1), 77-85. 